\title{
NAS FRONTEIRAS DO NÃO-TRABALHO: TRABALHADORAS POBRES E AS DEFINIÇÕES DE VADIAGEM NO INÍCIO DO SÉCULO XX
}

Lerice de Castro Garzoni*

\begin{abstract}
Resumo: Este artigo discute as definições de vadiagem para os habitantes do Rio de Janeiro no início do século XX. Os comentadores do Código Penal de 1890 buscavam explicar os termos do artigo 399 e de sua aplicação. Da mesma forma, Evaristo de Moraes dedicou algumas obras a esse tema, assim como os jornalistas e os literatos que colaboravam na imprensa. Mas esses debates nos meios letrados também eram mobilizados por pessoas comuns, o que pode ser observado nos processos de mulheres reincidentemente presas por vadiagem. Nas falas das acusadas e de seus defensores, é possível observar novos significados para a vadiagem e, ao longo do tempo, diferentes formas de definir a relação dessas mulheres com o mundo do trabalho.
\end{abstract}

Palavras-chave: Trabalhadoras, Vadiagem, Rio de Janeiro

Abstract: This article discusses the definitions of vagrancy for people that lived in Rio de Janeiro in the beginning of twentieth century. Authors who commented the Penal Code of 1890 discussed the terms of the article 399 and its applications. In the same way, Evaristo de Moraes dedicated some books to this theme, as well as journalists and literates who wrote to the press. But these debates among men of letters were also referred by common people, what is seen in the process of women that were arrest for vagrancy for several times. In these processes, the women that were arrested and the men who defended them gave new meanings to vagrancy and, through the time, it is possible to see changes in the way they defined the relationship of these women with the world of work.

Keywords: Women, Workers, Vagrancy, Rio de Janeiro

\section{APRESENTAÇÃO}

Em setembro de 1904, Maria Francisca Leonor foi detida na rua General Pedra, na cidade do Rio de Janeiro. Após uma rápida passagem pela delegacia de Santana, ela foi remetida para a Casa de Detenção ${ }^{1}$. Esse era o percurso daqueles que respondiam a processo referente ao artigo 399 do Código Penal, no qual a "vadiagem" era definida como uma contravenção. A impressão de quem lê diferentes processos desse tipo é que cenas como as vividas por Maria Francisca se repetiriam à exaustão no Rio de Janeiro do início do século XX. Mudassem os presos e os autores das prisões, as ruas e

\footnotetext{
* Lerice de Castro Garzoni é doutoranda em História Social na Universidade Estadual de Campinas. Este artigo é uma versão modificada do primeiro capítulo da sua dissertação de mestrado, Vagabundas $e$ Conhecidas: novos olhares sobre a polícia republicana (Rio de Janeiro, início século XX), defendida em fevereiro de 2007 na mesma universidade e com financiamento da FAPESP.

1 Processo por vadiagem em que foi ré Maria Francisca Leonor. AN, Série processo criminal da 8a. Pretoria do Rio de Janeiro, notação OR.3561, setembro de 1904.
} 
as circunstâncias em que se encontrassem, eram inúmeros os casos de homens e mulheres que cumpririam a saga dessa mesma "vagabunda".

Porém, contestando as qualificações elaboradas pelos policiais, muitas das mulheres presas nessas condições se consideravam legítimas "trabalhadoras" e argumentavam que eram injustamente arrancadas de suas ocupações cotidianas durante o desenrolar dos processos. As experiências dessas mulheres sugerem, portanto, descompassos entre as concepções de trabalho dos homens que criavam as leis, daqueles que as aplicavam e da realidade vivida pelas supostas "vagabundas". A falta de consenso sobre o que era "trabalho" dialogava diretamente com a imprecisão sobre o que era "vadiagem".

$\mathrm{Na}$ própria legislação republicana sobre esse tema, havia uma série de indefinições que eram discutidas nos círculos letrados e também fora deles. A diferença é que, enquanto os legisladores e comentadores tomavam a "vadiagem masculina" como um padrão, a partir do qual se viam autorizados a restringir os elementos que caracterizavam essa contravenção, os policiais que prendiam as "vagabundas" eram instados a debater com essas mulheres e seus defensores critérios relacionados à moralidade e à instabilidade de determinadas ocupações. Assim, os processos envolvendo mulheres reincidentemente presas por vadiagem nos permitem observar dimensões de gênero que eram silenciadas pelos homens de letras.

Nas primeiras décadas do século XX, embora prisões como as de Maria Francisca continuassem acontecendo, é possível observar mudanças na forma como foram encaradas e contestadas. Para entender esse movimento, é preciso acompanhar como definições de "vadiagem", "trabalho" e "não-trabalho" foram acionadas e ressignificadas nos processos de mulheres reincidentemente presas como "vagabundas", atentando para os argumentos dos diferentes sujeitos envolvidos nestes episódios.

\section{COM QUANTAS LEIS...}

Ser preso por vadiagem não era "privilégio" de poucos brasileiros no início do período republicano. No Rio de Janeiro, então capital do país, esse era um dos motivos mais recorrentes das prisões de muitos trabalhadores pobres, envolvidos com 
ocupações provisórias ou instáveis. Do ponto de vista legal, punir a vadiagem estava longe de constituir uma novidade. Desde o período colonial, quando o Brasil ainda era regido pela legislação portuguesa, passando pelo império e o Código Criminal de 1830, havia a previsão de penas para mendigos e vadios ${ }^{2}$. Com a perspectiva da abolição do trabalho escravo, a discussão sobre como controlar o não-trabalho ganha novos sentidos, o que pode ser observado na discussão do projeto de repressão à ociosidade em $1888^{3}$. No Código Penal da República, sancionado em 1890, a vadiagem passa a ser definida como uma contravenção e pode ser condenado aquele que, segundo o famigerado artigo 399:

\begin{abstract}
deixar de exercitar profissão, ofício, ou qualquer mister em que ganhe a vida, não possuindo meio de subsistência e domicílio certo em que habite, prover à subsistência por meio de ocupação proibida por lei e manifestamente ofensiva da moral e dos bons costumes. ${ }^{4}$
\end{abstract}

Essa forma de explicar aparentemente simples, centrada na ausência de ocupação e domicílio, está longe de ser precisa naquele momento histórico. Como definir "profissão, ofício, ou qualquer mister" quando as ocupações destinadas às classes pobres eram extremamente instáveis, como o serviço no porto ou aqueles relacionados a atividades domésticas? $?^{5}$ O que dizer sobre "domicílio certo" quando reformas urbanas e o encarecimento dos aluguéis, assim como tradições herdadas de outrora, conduziam a arranjos provisórios nesse quesito? ${ }^{6}$

Se os homens que forjavam as leis pareciam autorizados a ignorar essas particularidades, aplainando uma realidade da qual não participavam diretamente,

2 Para um histórico mais detalhadas das leis sobre vadiagem antes da república, ver MATTOS, Marcelo Badaró. "Contravenções no Rio de Janeiro do início do século" in Revista Rio de Janeiro, v.1, n.1, pp.16-23, 1993.

3 Sobre os debates dessa lei, ver CHALHOUB, Sidney. Trabalho, lar e botequim: o cotidiano dos trabalhadores no Rio de Janeiro da belle époque. Campinas: Editora da Unicamp, 2001, pp.64-89.

4 Código Penal Brasileiro (Decreto n. 847 de 11 de outubro de 1890) comentado por Affonso Dionysio Gama. São Paulo: Saraiva e Cia. Editores, 1923.

5 Sobre a instabilidade dessas ocupações ver, respectivamente, Arantes, Érika Bastos. O porto negro:cultura e trabalho no Rio de Janeiro dos primeiros anos do século XX. Campinas: [s.n.]. 2005. e, GRAHAM, Sandra L. Proteção e obediência: as criadas e seus patrões no Rio de Janeiro, 1860-1910. São Paulo: Companhia das Letras, 1992. Sobre as altas taxas de desemprego no período ver, entre outros, Damazio, Sylvia F. Retrato Social do Rio de Janeiro na virada do século. Rio de Janeiro: EdUERJ, 1996.

6 Essa questão era particularmente evidente na região de Santana, que reunia grande quantidade de diferentes tipos de habitações coletivas. Para os significados e sentidos políticos dessas moradias, ver CHALHOUB, Sidney. Visões da Liberdade: uma história das últimas décadas da escravidão na corte. São Paulo: Companhia das Letras, 1990, especialmente capítulo 3. 
aqueles responsáveis pelo policiamento direto nas ruas estavam em situação mais delicada. Não apenas porque deveriam responder a essas questões cotidianamente através de sua prática, mas também por compartilharem muitas das condições de vida das classes trabalhadoras. Ao seu lado tinham a lei, a indefinida lei, com a possibilidade de uma variedade de interpretações, tanto no sentido de reforçar, quanto no de contestar sua autoridade enquanto policiais.

Nas versões comentadas do código penal, que poderiam servir como apoio à ação dos policiais ou à defesa dos acusados, homens envolvidos com questões de direito procuravam explicar como caracterizar tal contravenção. Eles se centravam, sobretudo, nos detalhes sobre o que seria "profissão, ofício ou qualquer mister" e "domicílio certo". Uma tendência era complementar a definição do código citando outra, tirada em um acórdão de $1902^{7}$, segundo a qual:

\footnotetext{
A vagabundagem é um delito especial, subordinado à (sic) sua existência aos três seguintes elementos:

10. Falta de domicílio certo;

2‥ Não possuir meios de subsistência;

3‥ Não exercer profissão, ofício ou qualquer mister em que ganhe a vida.
}

Essa definição, como se constata no seu segundo item, chama a atenção para a possibilidade de que a posse dos meios de subsistência não fosse produto direto do trabalho habitual. Isso leva o autor das Annotações Theorico-praticas ao Código Penal concluir que "pode o indivíduo não ter habitação fixa, nem profissão, emprego ou ofício, e não ser vagabundo", complementando que "basta para isso que tenha renda para manter-se ${ }^{\prime \prime}$. Em relação ao domicílio, ele diz que, embora haja a necessidade de "habitação real", ela não precisa ser "fixa", nem pertencer "exclusivamente ao agente, basta que habite em casa de outrem". Quanto à profissão, destaca que é necessário que haja "habitualidade do trabalho", mas isso não implica em "exercício contínuo da mesma profissão".

\footnotetext{
7 Acórdão do Tribunal de Justiça de São Paulo de 26 de julho de 1902, Revista de Jurisprudência, volume 7, página 171 apud Código Penal Brasileiro (decreto n.847 de 11 de outubro de 1890) Posto em dia, annotado de accordo com o direito pratico e a jurisprudência dos nossos Tribunais, contendo ainda o prazo referente à prescrição de cada crime, bem como o calculo da graduação das respectivas penas por Affonso Dionysio Gama. São Paulo: Saraiva \& C. editores, 1923, pp. 498-9 e Annotações Theoricopraticas ao Código Penal do Brasil. De accordo com a doutrina, a legislação e a jurisprudência, nacionais e estrangeiras, seguido de um appendice contendo as leis em vigor e que the são referentes por Antonio Bento de Faria. Rio de Janeiro: Papelaria União, 1904, p.608.

8 Annotações Theorico-praticas ao Código Penal do Brasil, op.cit., pp.603-8.
} 
$\mathrm{Na}$ busca de construir um instrumento útil "aos que tiverem de aplicar ou solicitar a aplicação da lei penal", o autor acaba por colocar em evidência as brechas destas normas para quem quer que fosse. Isso porque, se os policiais poderiam lançar mão das indefinições em torno do Código Penal para acusar qualquer pessoa e, principalmente, em números cada vez maiores, os próprios acusados poderiam remeter a essas brechas legais para se defenderem ao longo dos processos, questionando a atitude e a autoridade dos homens que os prenderam.

Ainda segundo o artigo 399, as pessoas que fossem consideradas "vadias" deveriam cumprir pena de 15 a 30 dias de prisão celular e assinar "termo de tomar ocupação" dentro de 15 dias após sua liberdade. Para os reincidentes nessa contravenção, o artigo 400 do mesmo código previa que ficassem reclusos de um a três anos em "colônias penais que se fundarem em ilhas marítimas, ou nas fronteiras do território nacional", além da assinatura do mesmo termo. O código estabelece, portanto, linhas gerais, pois caberia às leis e aos decretos que seriam elaborados e sancionados nos anos seguintes a tarefa de detalhar os procedimentos relacionados ao local e ao cumprimento da pena.

Em todas essas definições e interpretações do código, não há nenhuma menção a diferenças de gênero nas formas de reconhecer e punir a vadiagem, o que pode gerar a ilusão de que "vagabundos" e "vagabundas" eram "iguais perante a lei". No entanto, retomando o artigo 399, é importante observar que há um terceiro elemento além da manutenção da subsistência e do domicílio; trata-se da referência a uma ocupação "manifestamente ofensiva da moral e dos bons costumes". Nos julgamentos das mulheres presas por vadiagem, esse era um ponto crucial porque, no intuito de apresentar provas, muitos policiais e testemunhas recorriam a argumentos relacionados à honra das acusadas, fazendo referências à sua devassidão moral e ao exercício da prostituição. Com isso, a conduta sexual passava a ser um dos critérios para julgar as mulheres, o que não acontecia nos casos que envolviam homens.

A questão do trabalho feminino também aparece como um problema, mesmo quando se tratava de ocupações que não diziam respeito, diretamente, à honestidade das mulheres. Afinal, mesmo nas falas de defensores, havia tensões no momento de justificar a presença das acusadas nas ruas, ainda que elas estivessem exercendo funções - a compra de mantimentos, por exemplo - relativas a uma atividade 
doméstica. Assim, policiais e defensores pareciam compartilhar a dificuldade em definir qual seria o perfil de uma "trabalhadora ideal", uma vez que as prisões por vadiagem, por mais que a padronização da lei e dos próprios processos possa obscurecer as especificidades de gênero, ocorriam em uma sociedade informada por diferenças fundamentais na forma de conceber a presença de homens e mulheres no espaço público.

Há tempos a bibliografia tem apresentado e discutido a existência de um ideal hierarquizado de organização social, no qual os homens são associados ao espaço público e as mulheres ao privado ${ }^{9}$. Concomitantemente, muitos estudos enfatizaram que grande parte das mulheres pobres circulava cotidianamente pelas ruas da capital, para exercer diferentes trabalhos ou, mesmo, em busca de lazer e diversão ${ }^{10}$. Se a presença dessas mulheres nas vias públicas fazia parte da rotina, isso não significa que estivesse isenta de inúmeros questionamentos por parte dos contemporâneos ${ }^{11}$. Importante dizer que as próprias mulheres não apresentavam uma postura de franco enfrentamento ou negação de valores relacionados à honra e à moralidade. No início do século $X X$, as acusadas por vadiagem e os policiais, assim como as demais pessoas chamadas a intervir nos seus encontros e embates, eram instados a discutir as ações e intervenções dessas mulheres no espaço público da cidade do Rio de Janeiro.

Da mesma forma que as diferenças entre vadiagem feminina e masculina não eram explicitadas no Código Penal, na legislação posterior sobre locais para punição e reabilitação, assim como controle da pena e da reincidência, essa questão continuaria

\footnotetext{
9 Com diferentes objetos e perspectivas teóricas, muitos trabalhos publicados na década de 80 remetem a essa questão. Jurandir Freire Costa, acompanhando o processo de "medicalização da família" ao longo do século XIX, afirma que "do ponto de vista dos higienistas, a independência da mulher não podia extravasar as fronteiras da casa e do consumo de bens e idéias que reforçassem a imagem da mulher-mãe". Cf. COSTA, Jurandir Freire. Ordem médica e norma familiar. Rio de Janeiro: Edições Graal, 1983 [1979], p.260. Ao analisar prontuários médicos do início do século XX, Maria Clementina Pereira observa a tendência de classificar como loucas mulheres que contrariavam determinados padrões de comportamento, como viajar sozinha ou ser independente financeiramente. CUNHA, Maria Clementina Pereira. Espelho do mundo: Juquery, a história de um asilo. Rio de Janeiro: Paz e Terra, 1986.

10 Ver, entre outros, SOHIET, Rachel. Condição feminina e formas de violência: mulheres pobres e ordem urbana, 1890-1920. Rio de Janeiro: Forense Universitária, 1989 e GRAHAM, Sandra L. Proteção e obediência(...) op. cit.

11 Isso fica patente nos julgamentos de crimes sexuais no início do século XX, como mostram Martha Abreu e Sueann Caufield. Cf. ESTEVES, Martha de Abreu. Meninas perdidas: os populares e o cotidiano do amor no Rio de Janeiro da Belle Époque. Rio de Janeiro: Paz e Terra, 1989 e CAUFIELD, Sueann. Em defesa da honra: moralidade, modernidade e nação no Rio de Janeiro (1918-1940). Campinas, SP: Editora da Unicamp, Cecult, 2000.
} 
relegada ao silêncio. O decreto de julho de 1893, por exemplo, determinava a fundação de uma colônia correcional, "para correção, pelo trabalho, dos vadios, vagabundos e capoeiras que forem encontrados, e como tais processados na Capital Federal". A questão do trabalho ao longo do cumprimento das penas seria retomada em lei de 1902 - em que fica determinada a criação de "uma ou mais colônias correcionais para reabilitação, pelo trabalho e pela instrução"12 - e no decreto de 1908, especificamente voltado para a reorganização da Colônia Correcional de Dois Rios, determinando um "trabalho imposto" que vise à "reabilitação moral (...) de modo a despertar-Ihes o sentimento da liberdade e os hábitos de auto coerção"13.

Segundo essas sanções legais, as prisões por vadiagem não eram meramente punitivas, pois visavam a "correção", não apenas pela imposição do trabalho, mas pela progressiva transformação dos condenados em trabalhadores disciplinados. A sucessão dessas leis e decretos, com especificações vagas e repetições, serve como indicativo da morosidade com que condições concretas - a criação das tais colônias e de seu regime de funcionamento - foram estabelecidas para execução desses objetivos. De qualquer forma, fica evidente a importância do trabalho para redefinir o caráter dos acusados, o que, como vimos, poderia ser muito mais ambíguo e sujeito a interpretações desfavoráveis no caso das mulheres.

Quanto às penas, embora o código estabelecesse a possibilidade de gradações $^{14}$, a maior parte das sentenças de condenação, principalmente nos primeiros anos do século XX, fixa 22 dias e meio de prisão na Casa de Detenção ou, em caso de reincidência, dois anos na Colônia Correcional de Dois Rios, na Ilha Grande. Apesar de homens e mulheres permanecerem separados dentro de cada uma dessas prisões, a inexistência de edifícios específicos para o cumprimento da pena de cada sexo poderia gerar dificuldades para os respectivos administradores ${ }^{15}$. Na verdade, funcionários de diferentes escalões estavam sujeitos a cobranças específicas quando

12 Ver item IV, artigo 1, lei n. 947 de 29 de dezembro de 1902.

13 Ver parágrafo 1ำ, artigo 63, decreto n. 6994 de 19 de junho de 1908.

14 Para a discussão das possibilidades de graduações da pena, ver Annotações Theorico-praticas ao Código Penal do Brasil, op. cit., p.610.

15 Sobre a ausência de colônias destinadas exclusivamente às mulheres e a forma como eram designadas nos relatórios dos administradores da Colônia Correcional de Dois Rios, ver SANTOS, Myriam Sepúlveda dos. "A prisão dos ébrios, capoeiras e vagabundos no início da Era Republicana" in Topoi: Revista de História. volume 5, número 8, jan-jun, 2004, pp.157-8. 
lidavam com criminosas mulheres, como aqueles responsáveis pelo registro de infratores no Gabinete de Identificação e Estatística.

Com essa instituição, consolidada em 1903, os dados sobre os acusados de qualquer crime ou contravenção passaram a ser centralizados e isso permitia aos autores de um processo o acesso à "ficha de antecedentes" de cada réu. Por meio dessa ficha se conhecia toda a trajetória pregressa de uma pessoa pelos meandros da justiça - em que delegacia havia sido presa, quando e quantas vezes, por quais delitos e se cumpriu a pena. No caso dos processos de vadiagem, isso representou uma nova forma de determinar os casos de reincidência, bem mais eficiente que a consulta aos "termos de tomar ocupação" ${ }^{16}$.

Nessa ficha organizada pelo Gabinete de Identificação e Estatística, havia uma parte dedicada à descrição física dos detidos, o que incluía, por vezes, "observações antropométricas", ou seja, a informação de medidas de diferentes partes do corpo, o que, segundo teorias criminologistas, indicava as tendências criminosas de cada infrator $^{17}$. O fato de mulheres serem submetidas a essas medições, sendo obrigadas a ficarem parcialmente despidas sob as vistas dos funcionários do gabinete, foi alvo de diversas controvérsias ao longo do tempo ${ }^{18}$. Então, por mais que a leitura da legislação nos dê a impressão de que "vagabundos" e "vagabundas" estavam submetidos aos mesmos critérios de culpabilidade e punição, a prisão de mulheres envolvia uma série de problemas diferenciados, relacionados à manutenção de certa "ordem moral", o que refletia na forma como essas acusadas e seus defensores se portavam diante das autoridades policiais.

Para compreender a dinâmica desses processos, ainda é preciso lembrar que todo esse arsenal de definições e procedimentos a respeito da vadiagem estava sob responsabilidade do chefe de polícia e delegados. Logo no início do período republicano, entre os inúmeros atos legislativos sobre reformas do aparato policial no

16 Ver artigos 52 a 68 do decreto n. 4756 de 05 de fevereiro de 1903.

17 Sobre as "medidas antropométricas" e sua relação com a antropologia criminal, ver GOULD, Stephen Jay. A falsa medida do homem. São Paulo: Martins Fontes, 1999.

18 Em 1906, o senador Barata Ribeiro questionava essas práticas de identificação voltadas para as mulheres discutindo a noção de "desonra" para as "vagabundas", ver Cunha, Olívia Maria Gomes da. "The stigmas of dishonor: criminal records, civil rights, and forensic identification in Rio de Janeiro, 1903-1940" in CAUFIELD, Sueann (et al) Honor, status and law in modern Latin America. Durham \& London: Duke University Press, 2005, pp. 295-315. 
Distrito Federal, a lei n.628 de outubro de $1899^{19}$, conhecida como lei Alfredo Pinto, concedia àquelas autoridades policiais a competência para processar algumas das contravenções do Código Penal de 1890, entre elas a vadiagem. Essa mesma lei trazia determinações sobre como deveria ser o desenrolar desses processos feitos nas delegacias:

Efetuada a prisão será incontinente (sic) lavrado o respectivo auto, em que, depois de qualificado o réu, deporão duas ou três testemunhas, recebendo em seguida a autoridade a defesa escrita ou verbal. No dia imediato serão ouvidas as testemunhas de defesa em número de três no máximo e, interrogado o réu, serão juntos os documentos e alegações que o mesmo apresentar e, ato contínuo remetido o processo ao respectivo pretor, para seu julgamento.

"Incontinente", "em seguida", "no dia imediato", "ato contínuo". Na própria redação da lei, uma série de expressões buscava evidenciar o ritmo a ser seguido pelos delegados ao instaurar um processo desses. Ao transferir a atribuição de conduzir processos por vadiagem para a polícia, uma das intenções era justamente impedir que se transcorresse muito tempo entre o flagrante e a sentença. Assim, esses processos eram compostos por apenas três partes: auto de prisão em flagrante, auto de interrogatório e julgamento, sendo que as duas primeiras ocorriam na delegacia e a terceira na pretoria. Diferente de outros tipos de processos criminais, os de vadiagem não eram compostos por um inquérito na delegacia, seguido por uma nova rodada de depoimentos na pretoria. Isso determinava que as falas emitidas na delegacia fossem definitivas, sendo o único suporte a partir do qual o juiz pretor avaliaria cada caso.

Muitas vezes, o juiz nem chegava a ver o acusado, fazendo com que o julgamento se resumisse à leitura dos autos e à emissão da sentença, ainda que isso fosse uma prática ilegal ${ }^{20}$. A responsabilidade por esses processos estava nas mãos dos

19 Ver Colleção das Lei dos Estados Unidos do Brazil de 1899. Rio de Janeiro: Imprensa Nacional, 1900.

20 Ver artigo 6으, parágrafo 5o, da lei n.628 de 28 de outubro de 1899: “apresentados os autos ao pretor, mandará este incontinente intimar o acusado para, no prazo de 24 horas improrrogáveis, apresentadas da intimação, requerer as diligências legais que tiver por conveniente a sua defesa, devendo tais diligências ter lugar nas 24 horas seguintes e na presença do acusado e, se este nada requerer ou for revel, seguir-se-á o julgamento imediato" (grifo meu). A ausência do acusado nos julgamentos por vadiagem é um aspecto bastante criticado por Evaristo de Moraes, ver MORAES, Evaristo de. Ensaios de Pathologia Social (...), op. cit., pp.7-8. Outra diferença fundamental era que os acusados por vadiagem permaneciam presos até o julgamento, o que não acontecia com os réus em outros tipos de processos: do xadrez da delegacia, os "vagabundos" eram enviados para a Casa de 
delegados de cada delegacia, o que determinava que os mesmos policiais que efetuassem as prisões em flagrante, em ruas específicas da cidade, conhecessem e estivessem diretamente envolvidos na construção dos processos por vadiagem. A despeito do que isso significava em termos de conferir atribuições judiciais à polícia, vale notar que policiais de baixo escalão, de um lado, e "vagabundas" e seus defensores, de outro, passavam a discutir e negociar os limites entre vadiagem e trabalho, vadiagem e honestidade, vadiagem e culpa, entre tantos outros, apresentando diferentes interpretações para repertórios comuns.

\section{... SE FAZ UM VADIO}

Envolvido com questões de direito, tanto na atuação como advogado quanto na confecção de ensaios, Evaristo de Moraes foi um dos que não hesitaram em dar sua contribuição sobre como pensar a vadiagem. Em 1921, publicou seus Ensaios de Patologia Social. Vagabundagem, Alcoolismo, Prostituição, Lenocínio ${ }^{21}$. Dividido em três partes, o livro se ocupa mais longamente da prostituição, sempre criticando a legislação em relação a cada um dos assuntos, apontando falhas e sugerindo mudanças. O autor do volume havia iniciado sua carreira como rábula na última década do século XIX, envolvendo-se na defesa de trabalhadores sindicalizados e de prostitutas que vinham sendo expulsas do centro da cidade. Na época da publicação do livro, Moraes já era advogado formado, contando com grande prestígio e projeção no cenário político ${ }^{22}$.

Ao introduzir o tema da "vagabundagem", o autor considera que, para lidar com esse "problema" era necessário investir em prevenção, assistência e repressão. No Brasil, porém, ele alegava que só esse último aspecto estava sendo atendido e, ainda assim, de forma insatisfatória, citando casos de aplicação das disposições do Código Penal e das leis de 1893, 1902 e 1908. Após essas considerações, Evaristo

Detenção, onde eram identificados pelo Gabinete de Identificação e Estatística e aguardavam o encerramento dos autos.

21 MORAES, Evaristo de. Ensaios de Pathologia Social. Vagabundagem, Alcoolismo, Prostituição, Lenocínio. Rio de Janeiro: Editora Leite Ribeiro, 1921.

22 Sobre a trajetória de Evaristo de Moraes, ver MENDONÇA, Joseli Maria Nunes. Evaristo de Moraes: tribuno da República. Campinas: Editora da Unicamp,2007. 
passava a expôr uma classificação dos vagabundos, dividindo-os em três grupos: os inválidos e enfermos, os acidentais e os profissionais ${ }^{23}$. Com isso, pretendia tornar preciso algo que as leis não haviam conseguido fazer: afinal de contas, quem era vadio?

Segundo o autor, a maioria dos vagabundos se enquadraria na primeira categoria, dependendo da "intervenção da ciência médica". Na sua visão, não só os acusados de vadiagem, como todos os indiciados, deveriam ser submetidos a exame de médico especializado. Defendendo-se de possíveis críticas que poderiam advir dessa argumentação, ele garantia que isso não significava "subordinar a justiça à ciência médica", mas tornar os procedimentos judiciais mais justos. Já o segundo grupo seria o de vadios "acidentais", composto por indivíduos válidos, mas sem possibilidade de trabalhar, desempregados ou egressos da prisão. Nesse momento, Evaristo comentava a relação entre vadiagem e a volubilidade de certos trabalhos não especializados:

\begin{abstract}
os trabalhadores que se empregam em certos serviços inferiores, o que os Ingleses chamam unskilled, cuja ocupação é incerta, vacilante e mal remunerada. Estes operários, sem habilitações especiais, e quase sempre não associados em sindicatos, sofrem, mais do que os outros, as alternativas do trabalho, fornecendo grande contingente à vagabundagem. São unskilled os carregadores, os empregados nas docas, os serventes de construções, que trabalham um dia sobre dois ou três, sem estabilidade. Não possuindo economias, não tendo os socorros de fortes organizações sindicais, vivem em crise permanente. A transformação deles em vagabundos depende de simples contingência acidental ${ }^{24}$.
\end{abstract}

A falta de estabilidade, de sindicalização e de economias explicaria a facilidade desses trabalhadores, "sem habilitações especiais", para se converterem em vagabundos. $\mathrm{O}$ autor utilizava uma expressão comum aos ingleses, unskilled, e chegava a listar algumas ocupações que se enquadrariam nesse perfil, mas não ponderava que a maioria dos trabalhadores brasileiros tirava sua subsistência dessa forma, como asseguravam os recenseamentos do período ou um simples passeio pelas ruas da

23 Conforme informa posteriormente, não formula, mas reproduz uma classificação que fora consagrada no Congresso de Paris de 1895. MORAES, Evaristo de. Ensaios de Pathologia Social, op. cit, p. 17.

24 Idem, p.19. 
capital. Outra causa dos "vagabundos acidentais" seria a própria prisão e policiamento inadequados das pessoas consideradas vagabundas:

\begin{abstract}
Devem ser inúmeros, no Brasil, os vagabundos criados e mantidos pela prisão. Enorme deve ser a proporção de desgraçados que se tornaram ociosos e se regimentaram, definitivamente, no exército da vagabundagem, em razão da entrada e permanência nas nossas mal cuidadas prisões e da conseqüente vigilância policial, tão estulta quão improfícua. [...] Imagine a hipótese de um operário desempregado, sem fortes amizades, sem recursos, sem família. Colhido, de surpresa, na rede policial, submetido ao monstruoso processo já descrito, sofre pena de seis meses de internação na desmoralizada Colônia. Ao sair, fica sob as vistas da Polícia [...] o já desclassificado social; que fica sendo desde então prisioneiro da Polícia, simples número do Gabinete Antropométrico, impossibilitado de trabalhar, em duas palavras - um forçado vagabundo... ${ }^{25}$
\end{abstract}

As reiteradas prisões inviabilizariam qualquer forma de emprego, quer pelo próprio estigma advindo dessa situação, pois a pessoa passava a ser um "desclassificado social", quer pela perseguição a que ficava à mercê um "prisioneiro da Polícia". Nesse momento, Evaristo enfatizava o caráter nacional desse tipo de problema, criticando fortemente a polícia brasileira e seus métodos de atuação ${ }^{26}$. A repressão, ainda mais a desse tipo, seria inadequada para os "vagabundos acidentais" que, em suma, não poderiam ser responsabilizados (e conseqüentemente punidos) pela sua condição. As distinções feitas pelo autor, bem como o histórico de atuações enquanto advogado, revelam um esforço de proteger pessoas socialmente desfavorecidas, vítimas recorrentes de injustiças e discriminações.

O foco de Evaristo de Moraes ao longo dessa discussão sobre a vadiagem eram os homens processados por essa contravenção, pois nos exemplos que empregava não havia referência às mulheres. Na verdade ele relatava situações, sobre a instabilidade das ocupações ou a reincidência na contravenção, que eram comuns tanto aos "vagabundos" quanto às "vagabundas". Afinal, nos registros da delegacia de Santana a maior parte das infratoras declarou estar empregada em "ocupações domésticas" 27 , o

25 Idem, p.23, grifos no original.

26 Bem entendido, o autor não considera que esse seja um problema exclusivamente brasileiro mas afirma que é particularmente acentuado no Brasil, como fica evidente na seguinte passagem: "os escritores estrangeiros, que dirigem acres censuras às polícias de seus países, por motivo da constante perseguição aos egressos das prisões, teriam ensejo para mais severas ponderações, se viessem apreciar, aqui, na capital da República, o proceder absurdo dos delegados, comissários e agentes da nossa polícia". Idem, p.23.

$2757 \%$ das infratoras registradas nos livros de ocorrência da $9^{\mathrm{a}}$. delegacia urbana, Santana, no primeiro trimestre de 1905, declarou estar empregada em "ocupações domésticas". Ver GARZONI, Lerice de 
que poderia ser considerado um daqueles "serviços inferiores", marcados pela instabilidade e falta de organização coletiva. Nos processos de vadiagem, como veremos adiante, muitas mulheres eram tratadas como "vagabundas conhecidas" e alegavam que eram vítimas da perseguição policial, argumentação que também era utilizada pelos seus defensores. Apesar das semelhanças, não havia menção às mulheres, o que se estendia à discussão da terceira categoria, referente aos "vagabundos profissionais":

o indivíduo que, sem domicílio certo, não tendo meios de subsistência, não exerce qualquer ofício ou profissão, não obstante ser válido, e, se lhe oferecer ocasião de trabalhar - constitui, em verdade, um perigo social ${ }^{28}$

Após longas ponderações sobre pessoas condenadas injustamente, Evaristo parecia propenso a concordar com a repressão daqueles que constituíam um "perigo social". O mais inquietante, nesse caso, é que não fornecia exemplos de quem eram esses "vagabundos profissionais" e como distingui-los na prática. Não problematizava que, no Brasil, apenas os pobres, fossem vagabundos voluntários, ou não, eram processados por vadiagem. Enfim, havia um recuo do autor em relação às proposições anteriores, com o reconhecimento de que a vadiagem deveria ser reprimida.

Tomados em conjunto, a classificação e os argumentos de Evaristo lembravam os posicionamentos de alguns dos comentadores do Código Penal. Tanto em volume publicado em 1904, quanto em outro datado de 1923, os autores reconheciam que a vadiagem só poderia ser punida se houvesse "voluntariedade do agente", isto é, a adoção consciente e livre escolha de determinado gênero de vida. Assim, aqueles que não podiam trabalhar ou não encontravam emprego, o que um dos autores chamava de "vagabundagem necessária", não deveriam ser punidos. Por outro lado, ambos reconheciam que a vadiagem que ameaçava a "tranqüilidade social" ou era "socialmente perigosa" não poderia passar impune.

Essa leitura do código aponta para um modo de compreender a vadiagem a partir de uma demarcação muito clara entre trabalho e não-trabalho, o que estava longe de corresponder à experiência das classes trabalhadoras naquele momento, já

Castro. Raparigas e Meganhas no Campo de Santana: elementos para uma história social da prostituição no Rio de Janeiro (1903-1907). Monografia de conclusão de graduação, 2005.

28 MORAES, Evaristo de. Ensaios de Pathologia Social, op. cit, pp. 28-9. 
que seus arranjos cotidianos em relação a trabalho e moradia eram bem mais complexos que essa dicotomia dada de antemão. Entre incorporar e criticar argumentos que serviam à repressão dessas pessoas, esses homens pareciam se colocar em uma situação delicada, ora reforçando, ora contestando a forma como as leis vinham sendo aplicadas pelo aparato policial ${ }^{29}$.

A discussão que propunham também aparecia como neutra em termos de gênero, não apenas pelo fato de não mencionarem exemplos relativos a mulheres, mas por tomarem a vadiagem masculina como padrão, supondo que os critérios para definir essa contravenção fossem os mesmos, independente do sexo do acusado. Isso é particularmente curioso no caso de Evaristo de Moraes que, como mencionamos, não só havia atuado como defensor de prostitutas como dedicara toda uma parte do citado livro ao tema da prostituição. Tratava-se, portanto, de um advogado experiente em casos relacionados a mulheres e, possivelmente, conhecedor das particularidades desses julgamentos, assim como dos argumentos que poderiam ser mobilizados para acusar ou defender pessoas do sexo feminino. No debate sobre a vadiagem, porém, ele não faz referências às "vagabundas", ainda que muitas das situações que descreva sejam válidas para elas.

Ao adotarem essa postura de neutralidade, Evaristo de Moraes e os comentadores citados passavam ao largo de questões particularmente polêmicas nos processos de mulheres reincidentemente presas por vadiagem. Uma delas se referia à definição de ocupações "ofensivas à moral", um dos critérios do artigo 399. Outra estava relacionada à delimitação de quais seriam ofícios legítimos para as mulheres, assim como os limites de trabalho e de não-trabalho em relação às atividades femininas. Com isso, as experiências das "vagabundas" nos revelam dimensões de suas atividades cotidianas que extrapolam essas discussões letradas sobre vadiagem. Por um lado, as definições legais, assim como as interpretações das leis e do próprio Código Penal, eram referências nos debates travados entre elas e os policiais. Por outro, as "vagabundas" e seus defensores forneciam interpretações alternativas sobre

29 Em relação especificamente a Evaristo de Moraes, Joseli Mendonça considera que "mesmo incorporando muitas idéias que serviam à justificação de medidas segregadoras das classes pobres tidas como perigosas pela própria pobreza - Evaristo matizava o alcance dessas idéias propondo limites à ação repressiva e da justiça penal”. Ver MENDONÇA, Joseli. op. cit.. 
o conceito de trabalho e as ocupações apropriadas às mulheres, ampliando nosso entendimento sobre sua relação com o mundo do trabalho.

\section{O QUE DIZEM AS VAGABUNDAS}

Todo esse imbróglio de definições que circulava naquele começo de século, envolvendo diferentes idéias sobre formas de condenar ou defender a vadiagem, poderia ser objeto de apropriações e redefinições ao longo dos processos relativos às vagabundas reincidentes. Uma das principais controvérsias se relacionava à forma pela qual cada um dos envolvidos se referia ao momento da prisão. O que seria, afinal, um flagrante de vadiagem? Os condutores, policiais que efetuavam as prisões, tinham suas falas registradas de forma padrão. Após serem qualificados, diziam onde e quando prenderam a ré, na maioria das vezes, porque ela estava "vagando", "perambulando", "flanando", "vagabundando" (sic) pelas ruas. O que incriminava, de fato, não era o lugar ou horário em que eram flagradas, mas o fato de fazerem isso constantemente, como hábito $^{30}$. Havia, portanto, o pressuposto de que esses homens tinham algum conhecimento prévio daquelas mulheres e, por isso, podiam afirmar os elementos do artigo 399, ou seja, que sabiam "de ciência própria" que elas não tinham profissão e domicílio. Pronto, eis a fórmula usualmente invocada para justificar as prisões de supostas vagabundas.

Por vezes, os condutores acrescentavam que a ré estava promovendo desordem ou envolvida em orgia, que andava "em franca ociosidade" ou era "ébria habitual". Certamente, a atribuição de cada um desses títulos (nada honrosos, diga-se de passagem) não era feita ao acaso, ou seja, dependia das circunstâncias da prisão, de quem era a acusada e da sua relação prévia com os policiais. De qualquer forma, essas alegações nos permitem ter uma visão geral de como os condutores legitimavam (e, talvez, entendessem) suas próprias ações. Os depoimentos das testemunhas, na maior

\footnotetext{
30 Vale destacar que a discussão sobre o horário da prisão, assim como as "horas" em que as mulheres eram usualmente vistas nas ruas, ocupou lugar de destaque em alguns processos. Ver processos de notações OR.4070 e OR.4050 ambos de junho de 1905 e $6 Z .8341$ de fevereiro de 1924. AN, Série Processo Criminal da 8a. Pretoria e da 3a. Pretoria Criminal, Rio de Janeiro.
} 
parte das vezes, seguiam esse mesmo roteiro, ainda que seja possível encontrar outras nuanças e tensões nas suas falas.

As acusadas, que poderiam falar em sua defesa no final do auto de prisão, apresentavam outras leituras sobre a situação que estavam vivendo. Por vezes, elas simplesmente invertiam as palavras dos condutores e das testemunhas, negando os elementos do artigo 399. Em um processo de 1905, Lídia afirmava que:

não é verdade o alegado contra ela pelo inspetor que a prendeu bem assim pelas testemunhas, que a má vontade destas contra ela acusada podia [ilegível] a esta falsidade, por quanto sendo ela acusada trabalhadora, donde tira seus meios de subsistência, e com domicílio, não compreendendo como pode ser acusada de vagabunda; sendo portanto, presa injustamente ${ }^{31}$

Nesse mesmo sentido, Rita afirmou em uma de suas prisões no ano de 1906:

não é desordeira, vagabunda, nem mulher de má nata, pois costuma a (sic?)estar empregada e com o produto do seu trabalho paga a casa em que reside. Que já declarou onde reside o que é fácil verificar-se; Que não deu motivo para prendê-la e ser processada ${ }^{32}$

Lídia e Rita, as autoras dessas defesas pronunciadas no auto de prisão, não só afirmaram ter ocupação e domicílio, como serem trabalhadoras e honestas. Por isso, podiam dizer que não compreendiam ou não tinham dado motivos para terem sido presas como vagabundas e que estavam sendo acusadas injustamente. Parece possível pensar que essa forma de se comportar, apresentando-se como o oposto da definição legal de "vagabunda" e invertendo as acusações de condutores e testemunhas, fosse lugar-comum entre as mulheres encontradas nos processos. Porém, não era bem assim, já que é possível observar outras tantas maneiras de se expressar e de se portar diante dos policiais.

Não raro, a acusada dizia que "nada fez para ser presa" ou que "nada tinha de que se defender" ${ }^{33}$. A idéia de que só era preso quem fazia algo errado mostra certa falta de entendimento acerca de um tipo de contravenção em que "fazer nada" - não trabalhar, andar em ociosidade - poderia ser, justamente, o motivo da prisão. Mas as

31 Processo por vadiagem em que foi ré Lídia de Oliveira Ramos e outras. AN, Série Processo Criminal da $8^{\mathrm{a}}$. Pretoria do Rio de Janeiro, notação OR.4149, março de 1905.

32 Processo por vadiagem em que foi ré Rita de Cristo Rangel. AN, Série Processo Criminal da $8^{\mathrm{a}}$. Pretoria do Rio de Janeiro, notação OR.4730, maio de 1906.

33 Ver, entre outros, processos de notações OR.3344 de setembro de 1904, OR.4174 de dezembro de 1905, OR.5104 de março de 1907 e OR.8505 de setembro de 1911. AN, Série Processo Criminal da $8^{\mathrm{a}}$. Pretoria do Rio de Janeiro. 
falas dessas mulheres também podem ser interpretadas como certa indiferença por essa oportunidade de se defender ou ainda como uma postura de enfrentamento em relação aos policiais que conduziam o auto, como mostram depoimentos em que as acusadas não só assumiam que já haviam sido presas outras vezes, como articulavam esse fato com sua futura absolvição.

Nesse sentido vale acompanhar as falas de Maria Francisca Leonor, com quem se iniciou esse artigo, tanto no momento da prisão quanto no auto de interrogatório realizado no dia posterior. Na primeira ocasião, afirmou que "não tem trabalho por estar doente e não tem casa por que não tem dinheiro para pagar casa, e a (sic) de ser solta como o foi pela pretoria do Meyer onde respondeu a um processo, estando vinte e dois dias na detenção". No interrogatório, perguntado onde estava no momento da prisão, "respondeu que tinha sentado-se para cansada (sic) em uma porta e adormecendo foi presa e trazida a esta delegacia" e, quanto aos fatos a alegar em sua defesa, "respondeu que em juízo será solta por isso não precisa defender-se, pois não matou nem roubou e foi presa por achar dormindo portanto não se julga criminosa e há de ser solta como foi pelo juiz do Meyer"34.

Para Maria, não havia motivos que justificassem sua prisão. Afinal, não ter trabalho e casa não era fruto de sua opção, mas de contingências - falta de saúde e dinheiro - sobre as quais não tinha controle e, diferente do autor de sua prisão, não via mal algum em parar para descansar na rua e pegar no sono. Ela, a despeito do que as autoridades diziam, se definia como uma vagabunda "ocasional" - para usar a terminologia empregada por Evaristo de Moraes e conceito comum entre autores que comentavam o Código. Curioso notar que, tanto na versão publicada em 1904 quanto naquela de 1923, esses autores citam acórdão segundo o qual "o simples fato de ser encontrado dormindo na via pública, por si só, não significa vagabundagem" ${ }^{35}$. Não há como saber se a acusada em questão havia tido acesso ao conteúdo de tal acórdão, mas o fato é que mobilizara suas próprias concepções para afirmar a mesma coisa. Ainda destacava que "não matou nem roubou" e, por isso, "não se julga criminosa".

34 Processo por vadiagem em que foi ré Maria Francisca Leonor. AN, Série processo criminal da $8^{a}$. Pretoria do Rio de Janeiro, notação OR.3561, setembro de 1904.

35 Acórdão da Câmara Criminal do Tribunal Civil e Criminal do Distrito Federal, de 7 de outubro de 1903; O Direito vol. 92, p. 618 apud Annotações Theorico-praticas ao Código Penal do Brasil, op.cit., p. 608 e Código Penal Brasileiro (Decreto n. 847 de 11 de outubro de 1890) comentado por Affonso Dionysio Gama, op. cit., p. 499. 
Pela sua experiência anterior, em outra pretoria da cidade, Maria acreditava que seria absolvida novamente. O que ela parece não ter entendido é que ser solta após uma estadia de 22 dias na Casa de Detenção não correspondia, necessariamente, a uma absolvição. Pelo contrário, a prisão por 22 dias correspondia justamente à pena usualmente empregada para punir a contravenção de vadiagem, o que pode significar que fora condenada na pretoria do Meyer. Ela também parece desconhecer que, caso fosse considerada reincidente, ficaria muito mais tempo presa, pois, na tentativa de se defender, fornecia elementos que poderiam complicar ainda mais a sua vida.

Essa postura de Maria diante dos mecanismos do processo contrastava, em certa medida, com a de Olívia Maria de Oliveira ${ }^{36}$. Com um longo histórico de prisões na delegacia de Santana, essa mulher lançava mão de nomes diferentes em cada ocasião. Em um dos processos, condutor e testemunhas mencionaram esse fato como parte da acusação. Assim, na defesa, Olívia disse "que é verdade ter sido processada por esta delegacia com os nomes de Olivia de Oliveira e Olivia Maria da Conceição, mas isto fez por achar-se embriagada quando fora presa em agosto e setembro do ano passado, porém não é vagabunda sendo injustamente presa naquele espaço como o foi hoje". No interrogatório, disse "não ter residência, tendo sido presa na hospedaria onde dormia" e, perguntada sobre a troca de nomes, "respondeu que se trocou o nome foi para evitar a ser condenada e ir para a Colônia". No final, perguntada se tinha fatos a alegar em sua defesa, "respondeu que na Pretoria se defenderá pois a (sic) de sair solta e se for condenada a (sic) Colônia não a (sic) de morrer".

Como fica evidente, o uso de nomes supostos pouco tinha a ver com a bebida, pois constituía um artifício para ocultar que era reincidente e, assim, evitar que cumprisse a pena de dois anos na Colônia Correcional. Mas há um tom de desdém quando diz que não vai se defender diante dos policiais e sim na Pretoria, pois acreditava que o juiz a colocaria em liberdade, concluindo que "se for condenada a Colônia (sic) não há de morrer". Infelizmente, essas palavras parecem ter sido um tanto premonitórias já que no final desse mesmo ano de 1905 morreu na Casa de Detenção, antes de ser transferida para cumprir pena de dois anos, enquanto

36 Processo por vadiagem em que foi ré Olívia Maria de Oliveira. AN, Série processo criminal da $8^{\underline{a}}$ Pretoria do Rio de Janeiro, notação OR.4173, fevereiro de 1905. 
respondia a outro processo por vadiagem. Diferente de Maria, as outras prisões de Olívia haviam lhe permitido ter algum conhecimento da estrutura desses processos e, conseqüentemente, outro tipo de desenvoltura para lidar com eles.

Por outro lado, Olívia declarou que pernoitava em uma hospedaria, sem ponderar que esse fato poderia ser utilizado contra ela, para reforçar sua imagem de contraventora ou associá-la à atividade da prostituição, como é possível observar nos depoimentos das testemunhas em outros processos ${ }^{37}$. Diferente do autor das Anotações Theorico-Praticas de 1904, os policiais olhavam com certa desconfiança moradias que não fossem fixas ou aquelas compartilhadas entre diversas pessoas. $\mathrm{Na}$ verdade, os policiais forjavam gradações entre essas moradias, algo que não fora considerado pelo referido comentador. Afinal, se esses dados poderiam ser mencionados como indícios da contravenção nos processos, há que se considerar que muitos dos policiais também residiam em habitações coletivas, como o inspetor, de nome Pedro J. L. Bairão, que prendera Maria Francisca em fins de 1904.

Em sua rotina, os policiais pareciam operar com uma espécie de hierarquização dos diferentes tipos de moradia coletiva, tendo em vista o grau de estabilidade de seus moradores. Locais com grande volubilidade de pessoas, como as "hospedarias", eram recorrentemente depreciados e associados à imoralidade nas falas dos condutores. Quanto a Olívia, ou desconhecia as implicações negativas de se afirmar moradora de uma habitação coletiva desse tipo, ou, mais provável, não pudesse negar essa condição, tendo em vista sua intensa convivência prévia com os policiais daquela região. De qualquer forma, sua declaração conta como indício de que conferia pouca importância àquilo que as autoridades que conduziam o processo fossem pensar ou fazer, já que, como Maria, o foco de sua preocupação era a opinião do juiz.

Encontramos então, desde acusadas que se definiam como trabalhadoras, reforçando e invertendo os pressupostos de seus acusadores, até aquelas que não viam problemas em contar sobre prisões anteriores. Nesses primeiros anos do século $\mathrm{XX}$, era comum que juízes anulassem muitos desses processos iniciados nas delegacias por não respeitarem formalidades legais. Essa rotina parece ter feito com que muitas mulheres reincidentemente presas passassem a duvidar da capacidade dos policiais de

37 Ver entre outros, processo de notação OR.5752 de janeiro de 1907. AN, Série Processo Criminal da $8^{\mathrm{a}}$. Pretoria do Rio de Janeiro. 
conseguirem condená-las. A partir de meados da década de 1910, os processos ficariam cada vez mais sérios e formais em alguns aspectos.

Os policiais deixaram de processar mais de uma pessoa em um mesmo auto, resultado de operações conhecidas como "canoas" na gíria da época ${ }^{38}$. Por outro lado, eles continuavam empregando colegas como testemunhas, o que constituía um procedimento ilegal. Ainda assim, é visível que uma maior compostura dos policiais em relação aos aspectos formais dos processos determinou uma diminuição no número de anulações nos anos seguintes ${ }^{39}$. Em contrapartida, praticamente se silencia a voz das acusadas com o passar do tempo, pois quase nunca lhe era dada palavra no auto de prisão e as respostas dos interrogatórios eram bem mais monossilábicas e padronizadas.

\section{A DEFESA DAS VAGABUNDAS EM VOZES MASCULINAS}

Outras formas de se posicionar também podem ser acompanhadas nos argumentos dos homens que se envolviam na defesa dessas mulheres, redigindo textos que eram enviados ao juiz pretor. Fossem curadores, rábulas ou conhecidos delas, lançavam mão de diferentes estratégias para provar a inocência das acusadas, entre elas, questionar a definição de um flagrante de vadiagem, alegando que não era proibido por lei passear pelas ruas da cidade. Segundo Martinho José dos Prazeres, em processo de 1904:

isto de andarem passeando pela Praça da República, não serve de base para acusação e nem tão pouco para condenação, porque ainda não apareceu lei alguma que proíba a liberdade do passeio e portanto, não prevalecem as acusações feitas a elas ${ }^{40}$

38 Segundo vocabulário de Gíria dos Gatunos Cariocas, "canoa" e "canastra" têm o mesmo significado: "diligência organizada pela polícia para colher gatunos, desordeiros e vagabundos". Ver CARVALHO, Elysio de. "Gíria dos gatunos cariocas (vocabulário organizado para alunos da escola de polícia)" Boletim Policial, nos. 4, 5 e 6, 1912, pp.168-81. Agradeço ao professor Sidney Chalhoub por essa referência.

39 Observando as sentenças dos processos lidos, é possível constatar que, entre 1905 e 1911, 44\% deles foi anulado por causa de "irregularidades formais". Entre 1912 e 1925, essa porcentagem cai para $19 \%$.

40 Processo por vadiagem em que foi ré Izabel Tavares. AN, Série Processo Criminal da $8^{\mathrm{a}}$. Pretoria do Rio de Janeiro, notação OR.3776, março de 1904. Defesa redigida por Martinho José dos Prazeres. 
Alguns anos mais tarde, em 1910, Serapião Alcides de Figueiredo empregava argumentos semelhantes:

\begin{abstract}
A acusada foi autuada por vadiagem. Consta dos autos que a acusada foi presa na ocasião em que perambulava sem destino certo, etc.

Em que se baseou a polícia processante para impedir a acusada do passeio que gozava, subjugando-a na sua liberdade, encerrando-a no cárcere da delegacia e remetendo-a depois para a "Casa de Detenção"?

A acusada passeava tranqüilamente, não Ihe era imputada a pratica do menor delito, não tinha deste passeio a menor satisfação a dar à polícia se levava destino certo ou incerto, estava no exercício de um direito prometido em Lei, que faculta a liberdade de locomoção independente de passaporte ou salvo-conduto a todos os brasileiros e estrangeiros residentes e em trânsito pelo território nacional; e o local em que a acusada foi presa não é um território neutro regido por leis e regulamentos especiais, governado ditatorialmente pela soberania czariana da autoridade policial no seu despotismo absoluto, faz parte da comunhão nacional e é regido pelas leis gerais da nação. A prisão da acusada é um atentado ao parágrafo 13․ do art. 72 da Constituição Federal, lei em pleno vigor, que estabelece a prisão legal do indivíduo e, no caso vertente, não assiste justa causa, é um atestado provado, flagrante, da violência policial com todo o seu cortejo de arbitrariedades $^{41}$
\end{abstract}

Ainda que apresentem diferenças no modo de se expressar, os autores desses dois trechos empregam um mesmo argumento. O que os policiais viram como "vadiagem", esses homens diziam ser um "passeio" - algo completamente diverso de uma contravenção e, portanto, fora da alçada policial. Nesse sentido, a seleção de certos elementos da legislação, no segundo trecho principalmente, é uma forma de deslegitimar a ação da polícia, o que nos mostra que as leis não apenas eram ambíguas e indefinidas, como podiam ser escolhidas e mencionadas de forma estratégica, contra, inclusive, os agentes da lei. Esse mesmo procedimento era acionado pelos defensores ao contestarem autos em que mais de uma pessoa era processada ao mesmo tempo. Em 1906, o defensor Bruno Lemos argumentava:

Sendo a responsabilidade criminal individual, conforme a lei em vigor; claro é, que a autoridade processante, na formação da culpa, deve ouvir as testemunhas, sobre que, digo, sobre cada réu de per si, e não englobadamente, como acontece nos presentes autos.

41 Processo por vadiagem em que foi ré Alzira Maria da Conceição. AN, Série Processo Criminal da $8^{\mathrm{a}}$. Pretoria do Rio de Janeiro, notação OR.7974, abril de 1910. Defesa redigida por Serapião Alcides de Figueiredo. 
Essas irregularidades dão em resultado a anulação dos processos. Assim sempre entendeu o extinto Tribunal Civil e Criminal que absolvia a todos os indivíduos que eram processados em idêntica condição dos acusados presentes, quando aqueles, recorriam das sentenças, a que eram condenados. E ninguém melhor sabe que o Meritíssimo Juiz que os vai julgar, porque quando em exercício no referido tribunal, também assim o entendia, tendo com seu voto absolvido a muitos, nas condições referidas $^{42}$

Em um processo do ano anterior, Arthur Godinho lançava mão dos mesmos argumentos:

\begin{abstract}
no presente processo, onde se acham processadas três mulheres, contra letra expressa do artigo 25 do Código Penal; que diz que a responsabilidade criminal é individual, o que quer dizer, que quando as testemunhas depuseram em tais processos, devem depor sobre cada réu de per si; e assim o entendia o extinto Tribunal Civil e Criminal, que sempre deu provimento às apelações em tais casos, mandando por em liberdade os acusados. E disto ninguém melhor que Meritíssimo Juiz que tendo que julgar o presente processo, conhece porque quando estava em exercício no referido Tribunal [trecho ilegível] o entendia ${ }^{43}$
\end{abstract}

Nessas duas defesas, os homens remetiam à questão da responsabilidade penal e à forma como foi tratada nos processos. Mais uma vez, elementos legais são citados para questionar os policiais. Os homens que redigiram essas defesas não só sabiam da recorrência das anulações e articularam isso a favor de suas clientes, como fizeram apelos mais pessoais, lembrando que o "Meritíssimo Juiz" Luiz Augusto de Carvalho e Mello, que ocuparia o cargo de juiz pretor da pretoria de Santana até 1911, deveria ser coerente aos seus posicionamentos e atuações passadas. Aparentemente, a questão da vadiagem ficava à margem nessa discussão, pois não se questionava o que as testemunhas haviam dito, mas a maneira como seus depoimentos foram recolhidos. Essa argumentação contra processos que envolviam mais de uma ré acabava por colocar certos limites a um procedimento comum na polícia daquele período e bastante relacionado à repressão da vadiagem: as famosas "canoas".

42 Processo por vadiagem em que foi ré Inácia Maria da Conceição e outras. AN, Série Processo Criminal da 8a. Pretoria do Rio de Janeiro, notação OR.4347, janeiro de 1906. Defesa redigida por Bruno Lemos.

43 Processo por vadiagem em que foi ré Olga Maria de Souza Lima e outras. AN, Série Processo Criminal da 8a . Pretoria do Rio de Janeiro, notação OR.4357, julho de 1905. Defesa redigida por Arthur Godinho. 
João do Rio havia presenciado uma dessas empreitadas quando um delegado o convidou a visitar um dos "círculos infernais" da cidade. O cronista descreveu essa visita em "Sono calmo", lembrando que Oscar Wilde e Jean Lorrain, assim como jornalistas franceses, haviam feito programas semelhantes e que, portanto, "era tudo quanto há de mais literário e de mais batido". Após descrever a passagem por uma hospedaria, o autor contava que:

\begin{abstract}
Nesse momento ouviu-se o grito de pega! Um garoto corria. O cabo precipitou-se. Já outros dois soldados vinham em disparada. Era a caçada aos garotos, a "canoa" vinha perto. Tinham pegado uns vinte vagabundos, e pela calçada, presos, seguidos de soldados, via-se, como uma serpente macabra, desenrolar-se a série de miseráveis trêmulos de pavor ${ }^{44}$
\end{abstract}

Para muitos dos "vagabundos" presos nessas diligências, os policiais nem se dignavam a abrir processos, deixando-os detidos irregularmente por tempo indeterminado. Nos casos em que havia os processos, não hesitavam em colocar vários em um único documento, o que poderia gerar críticas por parte dos defensores, como as que acompanhamos acima. Já na imprensa, algumas descrições dessas "canoas" enfatizavam o caráter positivo dessas ações, principalmente nos meses imediatamente posteriores a chamada "Revolta da Vacina". Sob os títulos "Canoa' louvável", "Canoas Moralizadoras" e "Prisões", o Correio da Manhã elogiava os esforços de delegacias suburbanas no início de $1905^{45}$ :

Ontem, à noite, o inspetor Câmara, com o louvável afã de fazer a higiene moral do Meyer, realizou uma dessas memoráveis "canoas" conseguindo pescar seis gajos, esfarrapados e da mais perigosa espécie. Prossiga o pessoal da 16a nesse empreendimento moralizador e terão os moradores de sua zona, razão de sobra para muito aplaudi-lo.

Associando "canoas" a medidas necessárias para a "higiene moral" e destacando o perigo dos seus alvos, o jornal considerava importante incentivar sua continuidade. Importante destacar que essa folha estava longe de ser partidária da polícia, não hesitando em publicar críticas e denunciar gestos violentos ou ineficientes. $\mathrm{Na}$ verdade, os posicionamentos dos jornais variavam conforme seu alinhamento

44 RIO, João do. A alma encantadora das ruas. Rio de Janeiro: Secretaria Municipal de Cultura. Dep. Geral de Documentação e Informação Cultural, Divisão de Editoração, 1995 [1908], p.124.

45 Notícias publicadas, respectivamente, em 17/03/1905, 18/03/1905 e 21/03/1905. Para a descrição de uma "canoa" realizada pela 9a circunscrição urbana, delegacia de Santana, ver "Gatunos Presos" em 22/02/1907. 
político e ocorrências pontuais Em uma defesa apresentada em 1919, o autor selecionava justamente momentos em que a imprensa se posicionava contra a polícia $^{46}$. Além de anexar atestados de moradia e de ocupação das acusadas e criticar os procedimentos fraudulentos dos policiais, o defensor agregava recortes d'O Jornal, publicados dias antes, em 19 e 24 de agosto de 1919. O primeiro recorte era uma matéria de primeira página, na qual o próprio inspetor da Segurança Pública propunha medidas para controlar as arbitrariedades nesses processos. O segundo era parte da coluna policial, em que se publicavam, na íntegra, as sentenças de dois juízes que haviam anulado processos em que fraudes e irregularidades se associavam.

Se havia defesas que se centravam, quase que exclusivamente, em comentários sobre o desrespeito aos aspectos formais, havia outras em que os defensores buscavam criticar tanto a forma quanto o conteúdo dos processos, a fim de contestar o que os sujeitos envolvidos consideravam ser um flagrante de vadiagem e, mesmo a maneira como mencionavam o artigo 399. Em 1909, Fernando Lupper Fortes Teixeira argumentava:

\begin{abstract}
Entretanto tratando-se de testemunhas de vista é de notar, senão de estranhar, que só pelo fato de uma pessoa perambular pelas tavernas, não se poderá chegar à conclusão tácita de que a mesma pessoa seja uma incorrigível vagabunda, e a prova mais clarividente encontra-se no caso vertente em que sendo a acusada empregada e residindo à rua Luiz de Camões no.25 (conforme prova com o atestado e documentos anexos) efetivamente ao fazer as compras para os diversos misteres da sua profissão, tem por força perambular diariamente pelas tavernas situadas no perímetro do 4․ DP em demanda de cereais, pelo preço que mais lhe convenha.

Logo o depoimento das testemunhas do processo é falso como também falsa é a imputação delituosa, não só pela contestação da acusada na própria delegacia, como também pela palpável controvérsia com a prova documental apresentada pela mesma ${ }^{47}$
\end{abstract}

De início, o autor dessa defesa critica a forma como as testemunhas inferiam a vadiagem de Maria Rosa. Para tanto, o defensor dissociava o ato de "perambular pelas tavernas" da condição de "vagabunda incorrigível", retomando os elementos do artigo 399 referentes à ocupação e domicílio, o que a acusada poderia provar e, deixando de lado a questão da moralidade, algo que era acionado pelas testemunhas. Se a ênfase

46 Processo por vadiagem em que foi ré Flora Ribeiro. AN, Série Processo Criminal da 3a. Pretoria Criminal do Rio de Janeiro, notação 6Z.4949, agosto de 1919.

47 Processo por vadiagem em que foi ré Maria Rosa de Lima. AN, Série Processo Criminal da 8a. Pretoria do Rio de Janeiro, notação OR.7703, junho de 1909. Defesa redigida por Fernando Lupper Fortes Teixeira. 
recaía nos dados referentes ao cotidiano da ré, apenas pessoas que a conhecessem previamente poderiam atestar se ela era vagabunda. À parte esta discussão, vale observar que o autor conferia outro sentido para a presença da acusada nas tavernas.

Freqüentar esses locais era uma necessidade de qualquer mulher envolvida com serviços domésticos e servia para provar que, além de trabalhadora, Maria Rosa era prudente e zelava pelos interesses de seus patrões, já que andava à procura dos melhores preços. Ainda que o processo estivesse ocorrendo no 40 distrito policial, delegacia de Sacramento, região bastante conhecida por concentrar a chamada "prostituição de janela" desde meados do século $\mathrm{XIX}^{48}$, o defensor mostrava a perambulação pelas tavernas como algo lícito e favorável à mulher em questão, que vai de vagabunda a trabalhadora num giro e pela mesma evidência.

Essa idéia de que estar nas ruas era evidência de trabalho e não de desvio também pode ser localizada em processos da região de Santana. Em julho de $1905^{49}$, o curador de duas acusadas menores de 21 anos destacou que uma delas "tem profissão, que é a de cozinheira e se atualmente acha-se desempregada é devido à (...) saúde e que estava acidentalmente conversando com as duas outras acusadas quando o inspetor as prendeu"; em relação à outra, disse que "se foi encontrada na rua General Pedra é porque tinha ido naturalmente buscar remédio para medicar-se ou fazer qualquer outra compra". Uma terceira acusada falou em sua própria defesa e "declarou que se todos que andam nas ruas em seus afazeres ela acusada o é pois conversava naturalmente quando um Inspetor gordo que chamam Bairão a prendeu com as suas duas companheiras (sic.)".

Sem os cuidados do curador, que buscava legitimar o fato de suas curateladas estarem desempregadas e nas ruas, fazendo referência a problemas de saúde, a última acusada afirmou que, como outras pessoas, tinha seus "afazeres" e, portanto, era imprescindível que estivesse nas ruas.

Como vemos, acusadas e seus defensores eram constantemente instados a darem explicações sobre os motivos que haviam levado essas mulheres a transitar pela

\footnotetext{
48 Sobre "prostituição de janela", ver SCHETTINI, Cristiana. "Que tenhas teu corpo":uma história social da prostituição no Rio de Janeiro das primeiras décadas republicanas. Rio de Janeiro: Arquivo Nacional, 2006, capítulo 1.

49 Processo por vadiagem em que foi ré Olga Maria de Souza e outras. AN, Série processo criminal da $8^{\text {a }}$. pretoria do Rio de Janeiro, processo OR.4357, julho de 1905.
} 
cidade, já que a associação entre espaço público e imoralidade era recorrente naquele período, sendo acionada pelos policias a fim de legitimar prisões que, talvez, soubessem injustas. Isso porque, como alegam os defensores, esses homens deveriam ter alguma familiaridade com o cotidiano dessas mulheres e, inclusive, saber da impossibilidade de tantas delas comprovarem os requisitos básicos da não-vadiagem, como moradia e ocupação, o que seria tematizado em algumas defesas:

\begin{abstract}
As acusadas, pretas analfabetas, vivem de seu trabalho, ora como cozinheira, ora como lavadeira, vivendo sob o teto de seus patrões - e, portanto, como provar com recibo de casa - a residência fixa?

Desempregadas, devido à crise, procuravam emprego na ocasião em que foram presas - tanto que, no ato de prisão tinham consigo o "Jornal do Commercio" onde a lápis tinha as indicações das ruas onde precisavam criadas.

Como tem os efeitos o termo de compromisso assinado para dentro de 15 dias, tomar emprego honesto, se é presa 24 horas depois desse termo solta, e mais tarde presa de novo ${ }^{50}$
\end{abstract}

Nessa fala, o defensor acionava vários recursos: o primeiro é comentar sobre um aspecto comum da vida dessas mulheres, relativo a morar na casa de seus patrões, o que implicava em não ter como comprovar, por meio de recibos, o lugar onde residiam. Na seqüência, porém, dizia que as acusadas estavam desempregadas - o que implicava não ter patrão e, logo, moradia - e que isso era conseqüência da "crise" e não da má vontade das acusadas. Assumia, portanto, que elas não tinham ocupação e moradia no momento em que foram presas, mas remetia à idéia de "vagabundo ocasional", o que as eximia de culpa e estava relacionado às próprias condições de vida de mulheres pobres.

Interessante notar que o autor iniciava dizendo que se tratava de "pretas analfabetas" e, depois, comenta que portavam um jornal com "indicações das ruas onde precisavam criadas". São afirmações contraditórias que, por um lado, parecem ter a intenção de mostrá-las como vítimas e despertar compaixão e, por outro, enfatizar seu empenho na busca por um trabalho.

\footnotetext{
50 Processo por vadiagem em que foram rés Ambrosina da Soledade, Celina Maria de Jesus, Liberatina da Silva Bastos e Maria da Conceição. AN, Série Processo Criminal da 8ª. Pretoria do Rio de Janeiro, notação OR.3371, agosto de 1904. Defesa redigida por Alfredo Silva.
} 
Como é possível observar, havia diferentes modos pelos quais os defensores podiam se expressar quando escolhiam discutir os elementos centrais do artigo 399, relativos à ocupação, moradia e moralidade. Nessa última defesa, datada de 1904, o defensor assumia que as acusadas estavam desempregadas, mas de uma forma que as afastava do estigma de "vagabundas". O curador do processo ocorrido em 1905 também buscava atenuantes, relacionados aos problemas de saúde, para o fato de suas curateladas não estarem trabalhando. Enquanto isso, na defesa de Maria Rosa datada de 1909, o defensor construía uma imagem um tanto quanto idealizada de uma trabalhadora dedicada e fiel, que freqüentava as tabernas à procura dos melhores preços para seus patrões.

\title{
CONSIDERAÇÕES FINAIS
}

Os contornos desses textos escritos pelos defensores de mulheres presas por vadiagem mudaram ao longo do tempo. Entre o final da década de 10 e início da de 20, a apresentação das "vagabundas" como trabalhadoras morigeradas e, principalmente, regeneradas, passava a ser outra possibilidade recorrente nessas defesas. Em 1919, Manoel Gomes Pinto dizia:

\begin{abstract}
No entanto a acusada tem ocupação e domićílio certo e determinado, achando-se completamente regenerada, assídua ao trabalho, o que a polícia não quer admitir indo assim de encontro a todas as normas e princípios de direito, quer perante as leis, quer perante a qualquer princípio de crença justa e aceitável ${ }^{51}$
\end{abstract}

Em outra defesa, datada de 1921, Joaquim de Lima redigia um texto, em nome de Rosaria Soares da Costa, nos seguintes termos:

Como defesa, para esmagar o que dizem as testemunhas de acusação,
apresento para ser junto ao processo, um atestado de meu atual patrão,
que nele diz sobre o meu comportamento, que sempre foi honesto, muito
embora a polícia que me processou, diga que sou vagabunda o que não
ficou provado dos autos como verá o M. Juiz. A polícia me prendeu, quando

51 Processo por vadiagem em que foi ré Constância Maria José. AN, Série Processo Criminal da $3{ }^{a}$. Pretoria Criminal do Rio de Janeiro, notação 6Z.4567, outubro de 1919. Segundo a ficha do Gabinete de Identificação e Estatística anexada a esse documento, Constância havia sido ré em oito processos entre janeiro de 1915 e junho de 1918, sendo cinco por vadiagem. Defesa redigida por Manoel Gomes Pinto. 
eu ia buscar uma roupa, e tinha saído da casa de meu patrão onde resido, e me conduziu para a delegacia. Portanto M. Juiz, eu estou empregada, não sou vagabunda, e não sou presa há dois anos, o que prova que me regenerei por isso peço a V. Exa. a minha absolvição por ser de Justiça ${ }^{52}$

Ainda nesse sentido, vale observar os argumentos de Arthur Godinho, que defendia Flora Ribeiro em processo de 1919:

\begin{abstract}
Neste caso, trata-se de uma infeliz mulher que tem sido perseguida tenazmente, mas que, não é nem pode ser considerada vadia porque exerce um mister lícito: lavar e engomar para diversas pessoas, entre as quais estão os atestantes, não podendo ser tidos por graciosos estes atestados, visto como um deles é passado pelo gerente, a mando do patrão, de uma casa de negócio, fronteia a esta pretoria, e que não se prestaria em fornecer esse documento se não fosse verdadeiro o que declara ${ }^{53}$
\end{abstract}

Nos dois primeiros trechos, os defensores não negavam que as acusadas tivessem sido presas outras vezes e chegavam a reconhecer, implicitamente, que por motivos justos. Mostrar as acusadas como ex-contraventoras era uma diferença significativa, pois se tratava de um argumento que não estava presente em defesas redigidas no início da década de 10 . Mas, se haviam sido "vagabundas" no passado, os autores dos fragmentos transcritos acima destacavam que elas haviam se regenerado, se tornado "assíduas ao trabalho" e que apresentavam comportamento exemplar, algo que provavam por meio de atestados anexados aos processos.

Logo, não havia motivo que justificasse suas prisões naquele momento, a menos que prevalecesse a incompetência e perseguição dos policiais, o que os defensores destacavam nos últimos excertos. Fica muito clara uma associação entre trabalho e honestidade, assim como a preocupação em enfatizar esse último aspecto. Assim, embora a acusação aos policiais e as denúncias de perseguição tenham sido recorrentes em defesas escritas nos primeiros anos do século XX, há mudanças

52 Processo por vadiagem em que foi ré Rosaria Soares da Costa. AN, Série Processo Criminal da 3a. Pretoria Criminal do Rio de Janeiro, notação 6Z.6467, janeiro de 1921. Segundo a ficha do Gabinete de Identificação e Estatística, Rosária havia sido ré em quatro processos entre abril de 1912 e junho de 1918, sendo três por vadiagem. Defesa redigida por Joaquim de Lima.

53 Processo por vadiagem em que foi ré Flora Ribeiro. AN, Série Processo Criminal da 3a. Pretoria Criminal do Rio de Janeiro, notação 6Z.4722, março de 1919. Segundo a ficha do Gabinete de Identificação e Estatística, Flora havia sido ré em dez processos entre dezembro de 1912 e setembro de 1917, todas por vadiagem. Defesa redigida por Arthur Godinho. 
significativas na forma como essas questões eram abordadas. Em 1908, João Henrique dos Santos mobilizava esses argumentos da seguinte forma:

\begin{abstract}
A folha de antecedentes não prova coisa alguma contra a acusada. Ao contrário, prova contra a polícia.

Vejam-se quantas prisões sem base legal e quanto sofrimento inútil foi imposto à acusada! Respondeu a sete processos, dos quais cinco terminaram pela anulação e um pela absolvição.

Condenada, uma vez, em junho de 1906, não obstante a perseguição policial não conseguiram seus perseguidores preparar outro processo viável ${ }^{54}$
\end{abstract}

O autor empregava a "folha de antecedentes" para argumentar pela inocência da ré. Como vimos, esse material reunia todas as entradas anteriores na Casa de Detenção e era organizado pelo Gabinete de Identificação e Estatística ${ }^{55}$. Quando havia pouco ou nenhum registro nessa folha, isso era prova de que a acusada não era vagabunda, tampouco reincidente. Porém, quando havia uma folha razoavelmente preenchida, isso reforçava as acusações de vadiagem e, inclusive, a reincidência. 0 curioso é que na defesa acima, mesmo uma folha teoricamente comprometedora era apresentada como favorável. Algo semelhante pode ser observado em um texto de 1922, assinado por Manoel Otaviano Álvares:

\begin{abstract}
Meritíssimo Juiz julgador como se vê da folha de seus antecedentes se verifica como tem sido vítima de perseguições no entretanto a mais de um [ano] não tem sido incomodada e agora que se acha empregada a mais de 6 meses na casa do senhor Manoel de Azevedo, como cozinheira e lavadeira, como bem mostra o atestado junto a esta e tem também residência certa a Travessa das Partilhas número $108 .^{56}$
\end{abstract}

Novamente, a questão da "folha de antecedentes" era invocada para inocentar a acusada. Porém, enquanto no primeiro trecho o autor argumentava que todas as prisões precedentes haviam sido injustas, mesmo aquela que terminou em condenação, no segundo trecho, se destacava que a ré "a (sic) mais de um [ano] não

54 Processo por vadiagem em que foi ré Graziela Maria do Espírito Santo. AN, Série Processo Criminal da 8a. Pretoria do Rio de Janeiro, notação OR.6353,maio de 1908. Defesa redigida por João Henrique dos Santos Oliveira.

55 Para casos de mulheres que se recusam a ser identificadas, ver processos de notações OR.7703 de junho de 1909 e OR.8332 de novembro de 1911. AN, Série Processo Criminal da 8a . Pretoria do Rio de Janeiro.

56 Processo por vadiagem em que foi ré Dora Gomes da Silva. AN, Série Processo Criminal da 3ạ. Pretoria Criminal do Rio de Janeiro, notação 6Z.6988, agosto de 1922. Defesa redigida por Manoel Octaviano Alvares. 
tem sido incomodada e agora que se acha empregada", ou seja, a idéia da perseguição era combinada com evidências de que a mulher em questão estava exercendo um ofício e havia se regenerado ${ }^{57}$.

De forma geral, essa tendência de apresentar as supostas "vagabundas" como mulheres trabalhadoras e honestas, algo que se tornava característico a partir de finais dos anos 1910, implicava em aceitar os pressupostos mais básicos estabelecidos no artigo 399 - emprego, moradia, moral - e em não contestar o que seria trabalho e não-trabalho, ou seja, as particularidades próprias das vidas de mulheres trabalhadoras. Se, em alguma medida, esses elementos eram discutidos nas defesas faladas e escritas nos anos anteriores, isso praticamente desaparecia dos processos. No caso das acusadas, como vimos, não é possível acompanhar o que teriam dito para se defender, já que os condutores restringiam cada vez mais a sua participação. Os defensores, por sua vez, pareciam acompanhar as próprias transformações dos processos. Na medida em que passava a existir uma maior preocupação dos policiais com seus aspectos formais, esse deixava de ser o mote das defesas, como era nos primeiros anos do século XX. Em seu lugar, as defesas eram incrementadas com documentos que provavam ocupação e domicílio, por vezes associados com críticas à polícia e, quase sempre, com menções à boa conduta moral das acusadas.

Indicar essas mudanças não significa conferir um sentido único para as falas desses homens em cada momento. Afinal, mesmo os possíveis defensores dessas mulheres não deixaram de se influenciar por posturas e interpretações da lei repetidamente estabelecidas, principalmente quanto ao perigo social que "vagabundos" e outros freqüentadores da Casa de Detenção poderiam representar. Nesse sentido, vale acompanhar o texto escrito por Arthur Godinho em 1905, quando defendia duas menores:

Digne-se o Meritíssimo Juiz mandar vir a sua presença as acusadas e facilmente se certificará da torpe perseguição que lhe moveu a autoridade, processando como vagabundas e ébrias a duas moças menores de dezoito anos.

57 Para outros processos em que essa mesma argumentação é acionada - menção aos antecedentes da acusada, mas ênfase no fato de estar empregada há algum tempo - ver outros dois processos por vadiagem em que Flora Ribeiro foi acusada. Notação $6 Z .4949$ de agosto de 1919 e $6 Z .6879$ de abril de 1922. AN, Série Processo Criminal da 3a. Pretoria Criminal do Rio de Janeiro. Defesas escritas, respectivamente, por Carlos Costa e Arthur Godinho. 
Não é preciso mais que um rápido lançar de olhos por sobre as mesmas para se ter firme a conviç̧ão de suas idades. Pois bem, essa autoridade que querendo fazer-se muito correta e digna dos maiores apoios de reconhecimentos, atira no fundo de um cárcere a moças de menor idade em proximidade com a casta mais infame e mais nojenta da escoria social e sobrecarrega-lhes de injuriosas faltas $(\ldots)^{58 "}$

Ainda que fosse para defender a acusada e condenar os policiais, Godinho lançava mão de preconceitos correntes ao falar de "casta infame e mais nojenta da escoria social", ou seja, sua estratégia de defesa passava pela desqualificação dos encarcerados na Casa de Detenção, enfatizando o perigo social que representavam. Entre preconceitos e releituras dos textos legais, os defensores de mulheres reincidentemente processadas lançariam mão de diferentes definições de vadiagem, Ihes conferindo sentidos diversos e, por vezes, contraditórios. Nesse contexto, mesmo a forma como passam a se referir aos critérios do artigo 399 entre os últimos anos da década de 1910 e o início de 1920 mostrava uma aceitação parcial do discurso sobre o trabalho, já que conseguiam articular isso em favor de mulheres tidas como "vagabundas".

58 Processo por vadiagem em que foram rés Belmira Maria da Conceição e Isaura Olímpia Barroso. AN, Série Processo Criminal da $8^{a}$. Pretoria do Rio de Janeiro, notação 3899, junho de 1905. 